\title{
INDIVIDUALIZATION AND GLOBALIZATION PROCESSES INFLUENCE ON THE HUMAN FREEDOM MANIFESTATION SPECIFICITY IN THE XXI CENTURY CULTURE
}

\author{
(C) Elena V. Volokhova \\ South-Russian state polytechnical university of M.I. Platov \\ Novocherkassk, Russian Federation \\ science-almanac@mail.ru
}

\begin{abstract}
There is an attempt to address the impact of processes of individualization and globalization on the specific manifestation of human freedom in contemporary culture. The author highlighted and systematized the concept of freedom in the context of contemporary processes of globalization and individualization, creating the need to develop new life strategies of personality. It is shown that the continuum of the life strategy of personality allows to overcome the discreteness of segments of the socio-cultural reality and the environmental asynchrony through reaching a new level of self-realization.

Key words: freedom, philosophy, culture, people, globalization, individualization.
\end{abstract}

[E.В. Волохова Влияние процессов индивидуализации и глобализации на специфику проявления свободы человека в культуре XXI века]

Предпринимается попытка рассмотрения влияния процессов индивидуализации и глобализации на специфику проявления свободы человека в современной культуре. Конкретизировано и систематизировано понятие свободы в контексте современных процессов глобализации и индивидуализации, создающих необходимость выработки новых жизненных стратегий личности. Показано, что континуальная стратегия жизни личности позволяет преодолевать дискретность квантированных отрезков социокультурной действительности и средовую асинхронию за счет выхода на новый уровень самореализации.

Ключевые слова: свобода, фрилософия, культура, человек, глобализация, индивидуализация.

Elena V. Volokhova - candidate of juridical studies, assistant professor. South-Russian state polytechnical university of M.I. Platov. Novocherkassk, Russian Federation

Волохова Елена Викторовна - кандидат юридических наук, доцент. Южно-Российский государственный политехнический университет (Новочеркасский политехнический институт) имени М.И. Платова. Новочеркасск, Россия.

The processes of individualization and globalization are the epochal characteristics of modern sociocultural reality. Therefore, for a holistic dissertation research, it is necessary to consider personal freedom in the conditions of these processes.

Person's freedom under the globalization conditions. Globalization is one of the fundamental megatrends of the modern sociocultural space that transforms mankind into a single sociocultural integrity, which determines the continuing interest of modern scientists in this issue [11]. This is the process of the mankind gradual unification on a planetary scale. The globalization process has an ambivalent impact on the individual's freedom, in which both the borders expansion of the external freedom occurs due to the new communication types emergence, and the leveling of its manifestation ways by imposing uniform cultural standards of life. This process leads to the unification of cultures and social institutions, implemented with the help of global communication networks, a single information space, international cooperation, the activities of financial institutions and the media. 
The researchers often see globalization roots in the causes of economic nature. Calling globalization a kind of capital entelechy, P.N. Kondrashov and K.N. Lubutin notes that observed in globalization "...desire for total expansion immanently presupposes the allround development of the individual" [12, p. 53]. From their point of view, it is globalization that is designed to protect society from the anti-human support of the individual development under capitalism, its one-sidedness and wretchedness, through greater social interconnection and cohesion, which conflicts with private forms of appropriation.

In general, the concept of "globalization" is currently used in philosophical discourse in both negative and positive meaning. In the negative, it means a purposeful policy of the Western world, primarily the United States, in the field of creating a unipolar world, based on the desire for world domination. This understanding is basically established on the notion that the world is developing linearly forward and progressively, constantly becoming more complicated by a revolutionary and evolutionary path and enters a new higher level of development. This approach takes more into account the time category and pays little attention to the space category in terms of recognizing the diversity of sociocultural models of development. Only the Western path of historical development is taken as the basis, implanted as a model for the rest of the world, which is perceived as subject to unification, modernization, and Westernization. The scientists note the destruction of traditional social institutions within individual national cultures as one of the main negative consequences of globalization in this sense. In modern Russian society, this is most clearly manifested in the crisis of the family institution, which is becoming one of the key factors of the threat to social security [22, p. $85-88]$, which requires the formation of a human security culture as a result of joint and systematic efforts by society as a whole [20].

In a positive sense, the "globalization" category implies a comprehensive and fullscale process of transformation and global distribution of specific types of organization, sociocultural relations and interactions, proceeding from the most advanced in the civilizational sense of the world. More objective and measured analysis of globalization processes and personal freedom specificity manifestation in it leads to the conclusion about the given processes contradictory character. V.V. Mironov writes truthfully about that: "If integration processes act as one side of globalization, then the back side, on the contrary the processes of disintegration..., which influence in a destroying way cultural, political, economical and even personal peculiarities, threatening with the individual identity deprivation, separate cultures, often just suppressing and dissolving them in the superculture of Americanize type" [18]. Thereat the given processes aggression becomes the threat, not only for personal freedom, but also for a person living world in whole. Herewith, as academician V.S. Stepin emphasizes, globalization recessionary character is increased by the fact that it happens on the back of other global character crises, possessing the generally planetary character, to the number of which he refers "ecological crisis, anthropological crisis, all accelerating processes of estrangement, invention of new instruments for massive destruction, threatening with destruction for all humanity..." Thereat, as Academician V.S. Stropin stresses, the globalization crisis nature is reinforced by the fact that it is taking place on the back of other global crises, including "the ecological crisis, the anthropological crisis, the accelerating processes of alienation, the invention of new and new means of mass destruction threatening to ruin the all humanity ..." [21, p. 697]. Nevertheless, V.S. Stepin sees scientific and technological innovation and economic determinants in these processes. Under the current development conditions of socio-cultural space, the most important forms of globalization manifestation are: information, religious, economic, political, territorial, demographic and other.

Information wars are the form of the globalization information realization, which are conducted for various reasons, but not least in order to "... create a subjective sense of freedom with objective unfreedom" [2, p. 11]. At that, it is necessary to distinguish between real freedom and the feeling of freedom, for "... a person feels free if his imagination 
does not go beyond his actual desires, while neither one exceeds the ability to act" [6, $p$. 23-24]. But mainly the ability to act according to one's desires is considered to be freedom. This implies that balance is achievable either by reducing the desires and intensity of the imagination, or by increasing the ability to act. At the same time, when only a subjective sense of freedom is cultivated, then a person can be satisfied with his fate even if his life is completely far from being objectively free.

Getting used to the lack of freedom and to some extent realizing the limits of permissible, a person learns to be free within the limits of what is permissible, even if it is extremely small. For instance, a person whose real freedom is reduced to the monitor screen of a computer, connected to the Internet, which in itself becomes an epochal trend of modern simulated reality, remains free (more accurately feels freedom), at least in the network space itself. Virtual reality gives, though a surrogate, but quite effective sense of freedom, allowing a person to experience himself repeatedly in various situations, because it "... does not know the limitations for the freedom resources, and in it a person (unless there is a special arrangement) does not interfere with other people freedom" [17, p. 13]. Realizing the widest spectrum of personal intentions, virtual reality appears to be the contrast to the present being, simulacrum, illusion, cyberprosthesis of social reality.

But this does not prevent it from existing and used as a phenomenon involved in solving the problem of freedom of modern man. Therefore, the position deserves attention to the wave, according to which "... henceforth the subject of freedom is inextricably linked with virtual reality" [17, p. 16]. Under the modern conditions, almost all key spheres of life are at the mercy of global information networks that generate a new world based on network, virtual and interactive principles.

A modern man is subjected to illusory perception of freedom. Due to the activity of the mass media, "... millions of people become witnesses of events that occurred in different places, and they are attached to the same cultural experience, which contributes to the unification of their tastes and preferences" [7, p. 38]. Mainly therefore free choice of live realizing styles of a modern person becomes more illusive. But because of virtual simulacrificial reality introduction into the modern person's life, the existence becomes more illusive.

Digital economy, distance learning, electronic control, virtual relations, communities and etc. have already come into the world of personal routine. At that, not only statepolitical, but also economic, market mechanisms that contribute to "... the acceleration of the synthesis of national economies into a single global system that has engendered the communication convergence of industrial countries ... are entering the key determinant of globalization processes" [3, p. 71]. But we should not forget that the information and economic forms of globalization have a very powerful influence on all socio-cultural processes, which in turn determine the specifics of interpersonal relations, as well as the processes of personal identity.

In this sense, globalization has a negative impact on the individual, as genuinely free is only that who considers to be free inside, and that means that he has an accurate structure of personal identity. However personal identity under the globalization conditions becomes dynamic and unstable. At that a person is released from prescribed social role, and "....identity maintenance turns into the constant self-identification process" [2, p. 12]. This brings to the fact that being under constant impact of global culture, a person experiences the feeling of forlornness and exposure, that are compensated for acceptance of dictated primitive forms of self-realization within the frameworks of social ties in the space of informative-communicative nets. This leads to the recovery of traditional societies elements that control the mass consciousness of its subjects (i.e. communication in these networks is controlled).

Political globalization has also a direct impact as on the states freedom, so on their people. It is realized with the help of ideology, on which the global world order can be 
based and which becomes a powerful and indispensable tool for building the world order itself and its main trends. In addition, "towards the end of the twentieth century, representative democracy dangerously approached risk and the possibility of its "creeping" transformation into totalitarianism" [13, p. 11]. The fact is that multimillion population masses endure only such democracy, which is based on constant manipulation, political lobbyism, separation of electors from voters, etc. Modern civilization is so complex that in order to preserve its existence, it requires more control over the processes, occurring in it, which cannot, but change the limits of human freedom. But this can lead to the fact that the introduction of information technology in the daily life of a modern person will strengthen totalitarian trends in the scale of comprehensive and multidimensional control.

Furthermore, in the processes of globalization, there is a tendency to increase the importance of traditional religious values, the dissemination of which, however, leads not only to stabilization (within intra-religious relations), but also to destabilization of the world order (due to inter-confessional differences and conflicts). It is no coincidence that the reaction to globalization, manifested as aggressive Westernization, is the activation of nationalist movements, as well as religious fundamentalism.

Another problem, arising from the consideration of freedom in the context of the globalization process is the problem of using the liberal-democratic paradigm of rights and freedom as a means for legitimizing and justifying geopolitical expansion. How correctly A.V. Bakin emphasizes, "under the pretext of the need to restore human rights, violated by dictatorial regimes in a number of countries, from the side of developed democracies at the end of XX-beginning XXI century a series of politico-military actions, received the title "humanitarian intervention" [4, p. 3]. All this leads to the violation of other states sovereignty by the expansionist states, to the shaking of international law principles, to the increasing of military-technical resources role in solving geopolitical issues, and to simplifying the implementation of geopolitical expansion. In addition, there is a process of cultural invasion, which is "the implantation of cultural elements and life models of one community in the culture and spheres of another community life through the impact of material and nonmaterial resources on its consciousness and life" [4, p. 9]. The results of the latter, as well as geopolitical expansion in general, are difficult to evaluate unambiguously, as positive and negative sides can be emphasized in them for both sides.

Development of polyculturism, which assumes not the absorption of weak cultures by strong, but relatively equitable dialogue of cultures, egalitarian interdependence and cultural interchange is considered to be one of the ways to counter the negative globalization influence, transforming sociocultural relations from national to transnational level. It is no coincidence that Academician RAS V.A. Lektorsky declares: "The only way to avoid a total clash of cultures (and such danger is real) is the establishment of a dialogue between them" [15, p. 386]. Dialogue is possible when there is mutual understanding, and it, in its turn, actualizes only with a certain commonness of value positions and also the dialogue methods. Of course, the cultures themselves cannot conduct a dialogue. This is a metaphor. In reality, if it is carried out, then it is led by specific people, social groups, communities and institutions on the basis of observance of legal norms and cultural traditions. However, one cannot but admit that in the international law system there are many gaps that hamper the solution of existing global problems of a global, transnational level.

Multipolarity, which is associated with the world stability in whole and security of illprotected countries in particular, is considered to be alternative globalism. Moreover, "multipolarity is important as a factor, providing preservation and necessary diversity in the evolutionary system, in the given context - culture diversity" [10, p. 221]. Today numerous cultures exist by means of intersection and interpenetration. Actually the culture itself, as V.V. Mironov writes, "... appears before us as a kind of whole, consisting of subsystems of local (national), fairly closed cultures" [19, p. 449]. At the same time, the excessive diversi- 
ty of cultures is the reason for inertia and lack of mobility in terms of the progressive development of the world community.

As academician of RAS L.I. Abalkin correctly emphasizes "in contrast to globalization, culture is national in itself" [1, p. 42]. A unite world panhuman culture is possible only at the expense of primitivization and the ultimate simplification, and subsequently the death of national cultures. The preservation of these, we repeat, is achievable only through the dialogue. It should be emphasized that this is primarily a value dialogue, in the process of which the individual's freedom in the context of globalization takes the form of freedom from orientations, generating false ideas and values that are not characteristic of a highly developed and self-fulfilling personality. "The world of culture is multicolored, and this is its dignity. Acquaintance with a foreign culture enriches the outlook of a person, brings him closer to other countries, forms mutual respect between people" [1, p. 42], - fairly emphasizes L.I. Abalkin. Only under the conditions of cultural identity and their equitable dialogue the creativity of the personalities representing these cultures find its meaning. And if we take into account the fact that first of all, "... in the process of creativity the individual has the opportunity to achieve the state of freedom" [2, p. 15], the character influence of the world globalism current state on the specificity of the personal freedom manifestation becomes clear.

It is worth noting that in modern conditions there is a dialectic of globalization and nationalism, and besides "... the interconnection of integrative and disintegrating processes is significantly complicated, permanently provoking and giving birth to "nationalisms" of different kinds and meanings" [8, p. $14-15]$. They enter into an alliance with various (up to racist, extremist and terrorist) ideologies and practices that stimulate disintegration of powerful multinational states into quasi-states, the formation of which is supported by a number of advanced powers. At the same time, the nationalistic tendency of modern eurocentrism actualises the emergence of new forms of globalization on the basis of programs for the improved application of philosophical and religious ideas and values. It is not by chance that in our country the wave of the modernization process that swept the country in the last decade of the twentieth century and the beginning of the 21st century was supplemented by counter-modernization processes that marked "... a significant strengthening of state power, certain restrictions in the sphere of individual freedom" [14, p. 38]. It was realized that Russian civilizational identity is implemented, as involving society elements, equalizing it with the world tendencies, so with preservation and development of national potential on the basis of elaborated internal political management.

At the end of the 20th and beginning of the 21st century, scientists are increasingly becoming aware that the linearly progressive paradigm of civilizational development is limited, that the civilizations of the East have no less potential and resources for a sociocultural dialogue than Western countries. Analyses of social systems by G. Haken, I. Prigogine, G. Nicholas, and others prove that they develop in conditions of organization and disorganization, in which the state of disequilibrium is replaced by a more rigid and ordered social structures formation. This proves the idea, about that history and globalization modern processes proceed nonlinearly that becomes one of the basis for forecasting of the future world situation, which will be characterized by the contest between alternative national globalization strategies on the back of intercivilizational synthesis, and also creation conditions for individualization forming of person life strategies.

Person's freedom under the individualization conditions. The modern culture represents a phenomenon at first sight of processes paradoxial combination of universalization and globalization cultures, from one side, and the individualization processes of possibilities and styles of the life self-realization - from the other. However individualization on the back of accelerating globalization processes today became the reality not only for the West, but for the whole world countries, demonstrated in various forms, including Russia. Post-Soviet reality, which deprived Russian person of paternalistic custody from the gov- 
ernment side, became the powerful factor of the life strategies individualization under the condition of the new possibilities of personal freedom self-transference.

Individualization in the modern culture is manifested in emancipation from traditional forms of personal relations social standardization, from the viewpoint of domination and submission that brings not only to the space release for a person life strategy forming, but also to the stability feeling deprivation, uncertainty increase, fear, risk and threats. Under the conditions of corresponding kind of reality, a person has to remain himself and transcendent a personal freedom only on the basis of daily efforts of his processual-actual me. Realization of long-term strategic goals and challenges becomes problematic in the individualized reality, generation succession and traditional family values significance is ruined.

Sociocultural reality individualization problem is studied recently not only by the western scientists [5], but also by the domestic researchers [9, p. $67-68$ ]. Thus, Z. Bauman, naming the modern society as individualized, proves that it cardinally differs from all the early forms of human existing, as today the former balance between personal and social is lost [5, p. 11].

The fact that individualization acts as epochal characteristic of the modern world in the context of personal life strategy forming, was conclusively demonstrated in doctorate thesis on philosophy M.B. Marinov, who emphasized: "Individualization -new social reality, where functional parameters of the existing social structures and person life trajectory cease coinciding. A person, remaining to live in the society, cardinally changes the configuration of social interactions that leads to the risks growth" [16, p. 4]. Hereof the necessity to study specificity of personal freedom self-transcendention in the new, early not occurring sociocultural conditions of individualization, grows.

Formation of person lifemeaning strategy in the individualized sociocultural space is connected not only with the new subjects production, but also with the new social relations construction, and also with self-dependence intensification and freedom of self-being projection. Individualization enlarges person's possibilities, releasing him from sociocultural design of values, strategies and meanings, opening the new methods of selfrealization under the conditions of primordial, social uncertainty and risk, recession level of stability and security.

The life in the individualized society, from the view point of M.B. Marinov, polarizes that leads to dichotomy of two key strategies: spatial (the place strategy), giving the more life perspectives in traditional and industrial society and temporal (the time strategy), which is more adequate to uncertainty, diversity and informatization of individualized society. At that two strategies in isolation from each other are destructive for a person. Spatial strategy does not fulfil a requirement of time, as basing on traditional communication forms, decreases the possibilities of self-transcendention of personal freedom in the personal selfrealization process. Temporal strategy subjects the modern person and his psychosomatic integrity to the constant risk and occurring in dangerous stress conditions. The objective requirement in the new life strategy of a person in the individualized society, according to M.B. Marinov, leads to the necessity of continuant strategy following, combining the advantages of both above mentioned strategies. He emphasizes: "Strategic thinking in such context has high degree of correlation with continuant thinking, basing on that not time continuance, not the world spatial extent are thought separately from the reality expansion process" [16, p. 14]. Thus, the continuant strategy allows overcoming discretisation of quantum sections of sociocultural reality, reconstructing the strategic continuity of person life biography, lost by individualization, and also overcomes the environment asynchronicity at the cost of the entering to the new self-realization level.

Summing up the results of individualization and globalization processes impact on person freedom manifestation specificity in the culture of XXI century, we lead to the following conclusions: 
1. The processes of individualization and globalization under the modern conditions act as epochal characteristics of the modern sociocultural reality. Globalization should be considered as one of the most foundational megatendencies of modern sociocultural space, turning the humanity into the united sociocultural integrity. The globalization process has an ambivalent impact on a person's freedom, under which can be as extension of the external freedom borders at the cost of the new communication types emergence, so the grading of its manifestation methods at the cost of intrusion of the unite cultural standards activity.

2. In the negative meaning under globalization one understands the purposeful policy of the western world, first of all USA, in the sphere of unipolar world creation, on the basis of which there is striving to the world domination. In the positive meaning the category of "globalization" implies the universal and full-scale transformation process and the world dissemination of concrete organization types of sociocultural relations and interactions, originated from the most progressive world governments in the civilizational meaning.

3 . Under the modern development conditions of sociocultural space the most important forms of globalization manifestation are: informative, religious, economic, political, territorial, demographic and others. Under this the modern person is subjected to illusive freedom perception.

4. Informative and economic globalization forms strongly influence on all sociocultural processes, which in their turn determine the specificity of interpersonal relations, and also processes of personal identity. In this meaning globalization has a negative impact on a person, as genuinely free only that person, who is free inside, which means he has a distinct structure of personal identity.

5. Political globalization is realized with the help of ideology, where the global world order can be based and which becomes the powerful and irreplaceable means of the world order and its tendencies construction.

6 . The tendency to the significance increase of traditional religious values, dissemination of which, however, leads not only to stabilization (within the framework of insideconfessional relations), but also to word order destabilization (in consequence of interconfessional disagreements and conflicts) is observed in the processes of globalization.

7. Multipolarity, which is associated with the world stability increase in whole and security of low protected in particular is considered to be alternative to globalism. Today the numerous cultures exist owing to their intersection and interpenetration. At the same time cultures excessive diversity is only the reason of inertia and stickness in the context of progressive development of the world society.

8. Dialectics of globalization and nationalism occurs under the modern conditions. History and the modern globalization processes proceed nonlinearly that becomes one of the basis for the future world situation forecasting, which will be characterized with contest between alternative national strategies of globalization on the back of intercivilizational synthesis processes, and also creation conditions for individualization forming of person life strategies.

9. Individualization in the modern culture manifests in release from traditional forms of personal relations social norms, from the view point of domination and submission that leads to not only release of space for person life strategy forming, but also to the stability feeling deprivation, uncertainty growth, fear, risk and threats.

10. The life in the individualize society is polarized that leads to dichotomy of two strategies: spatial, which gives the most living perspectives in traditional and industrial society and temporal, which is the most adequate to uncertainty, diversity and informatization of individualized society. At that both strategies in isolation from each other are destructive for a person. Objective need in the new life strategy in the individualized society leads to necessity to follow continuant strategy, combining the advantages for both above mentioned strategies. 


\section{Литература}

1. Абалкин Л.И. Глобализация мирового сообщества и культура // Лекции и доклады членов Российской академии наук в СПбГУП (1993 - 2013): в 3 т. Т. 3. СПб, 2013.

2. Абдрахманов Д.М. Проблемы влияния глобализации на свободу личности: авторефр. дис... канд. филлос. наук: 09.00.11. Уфра, 2006.

3. Аствацатуров А.Е., Басилаиа М.А. Глобализация и начала космогармонии // Век глобализации. 2009. № 2.

4. Бакина А.В. Либерально-демократическая парадигма прав и свобод человека как инструмент геополитической экспансии: автореф. дисс... канд. полит. наук: 23.00.02. Екатеринбург, 2008.

5. Бауман 3. Индивидуализированное общество. М.: Логос, 2002.; Элиас Н. Общество индивидов. М., 2001.

6. Бауман 3. Текучая современность / Пер. с англ.; под ред. Ю.В. Асочакова. СПб., 2008.

7. Володина Л.В. Проблема глобализации современного общества // Глобализация в социально-фрилософрском измерении. Сборник материалов конфреренции. СПб., 2003.

8. Гранин Ю.Д. Глобализация и национализм: история и современность. Социально-философрский анализ: автореф. дисс... док. филос. наук: 09.00.11. Москва, 2008.

9. Иноземцев В.Л. «Класс интеллектуалов» в постиндустриальном обществе // Социологические исследования. 2000. № 6.

10. Калинина Н.М. Глобализм и глобализация в свете синергетического мировидения // Кантовские чтения в КРСУ (22 апреля 2004 г.); Общечеловеческое и национальное в фиилософии: международная научно-практическая конференция КРСУ (27-28 мая 2004 г.). Материалы выступлений/ Под общ. ред. И.И. Ивановой. Бишкек, 2004.

11. Колосова О.Ю., Несмеянов Е.Е. Социокультурные трансформации в условиях глобализационных процессов // Фундаментальные исследования. 2015. № 214.

12. Кондрашов П.Н. Любутин К.Н. Глобализация и развитие индивида // Философия и общество. 2011. № 4 (64).

13. Косолапов Н.А. Свобода и несвобода в глобальном миропорядке // Международные процессы. 2004. Т. 2. № 6.

14. Кумскова Н.В. Глобализация и поливариантность моделей социокультурного развития // Вызовы современности и фрилософрия: Материалы «Круглого стола», посвященного Дню философии ЮНЕСКО. Кыргызско-Российский Славянский университет / Под общ. ред. И.И. Ивановой. Бишкек, 2004.

15. Лекторский В.А. Глобализация и культурное разнообразие // Лекции и доклады членов Российской академии наук в СПбГУП (1993 - 2013): в 3 т. Т. 3. СПб., 2013.

16. Маринов М.Б. Стратегия жизни личности в индивидуализирующимся обществе: Автореф. дисс... док. филос. наук: 09.00.11. Ростов-на-Дону, 2008.

17. Маслов В.М. Свобода и виртуальная реальность // Вестник Челябинского государственного университета. 2008. № 10.

18. Миронов В.В. Современные трансформации культуры // Лекции и доклады членов Российской академии наук в СПбГУП (1993 - 2013): в 3 т. Т. 1. СПб., 2013. 
19. Миронов В.В. Диалог культур и глобализационные угрозы // Лекции и доклады членов Российской академии наук в СПбГУП (1993 - 2013): в 3 т. / сост., науч. ред. А.С. Запесоцкий. Т. 3. СПб., 2013.

20. Руденко А.М. О необходимости системного подхода к формированию культуры безопасности человека в современной России // Проблема безопасности человека в современном мире: сборник материалов по итогам всероссийской научно-практической конференции 11 апреля 2017 г. / под ред. А.М. Руденко [и др.]. Новочеркасск, 2017.

21. Степин В.C. Стратегии глобализации и диалог культур // Лекции и доклады членов Российской академии наук в СПбГУП (1993 - 2013): в 3 т. Т. 3. СПб., 2013.

22. Степанова В.Н. Кризис института семьи как фрактор угрозы социальной безопасности современного российского общества // Проблема безопасности человека в современном мире: сборник материалов по итогам всероссийской научно-практической конференции 11 апреля 2017 г. / под ред. А.М. Руденко [и др.]. Новочеркасск, 2017.

\section{References}

1. Abalkin L.l. Globalization of the world community and culture // Lectures and reports of the RAS members in SBRHUTU (1993 - 2013): in 3 v. V. 3. SPb., 2013.

2. Abdrakhmanov D.M. The problems of globalization influence on the individual freedom: abstract of thesis of candidate of philosophy: 09.00.11. Ufa, 2006.

3. Astvatsaturov A.E., Basilaia M.A. Globalization and the beginning of cosmogarmonicity // The globalization century. 2009. No 2.

4. Bakina A.V. Liberal-democratic paradigm of human rights and freedoms as an instrument of geopolitical expansion: abstract of thesis of candidate of political studies: 23.00.02. Ekaterinburg, 2008.

5. Bauman Z. Individualized society. M., 2002; Elias N. Society of individuals. M., 2001.

6. Bauman Z. Flowing modernity. SBR., 2008.

7. Volodina L.V. The problem of modern society globalization // The globalization in the socio-philosophical dimension. Conference sourcebook. SPb., 2003.

8. Granin Yu.D. Globalization and nationalism: history and modernity. Sociophilosophical analysis: synopsis of a thesis of Ph.D. of philosophy: 09.00.11. Moscow, 2008.

9. Inozemtsev V.L. "The Class of Intellectuals" in Post-Industrial Society // Sociological Research. 2000. No 6.

10. Kalinina N.M. Globalism and globalization in the light of the synergistic worldview // Kant's readings in KRSU (22 of April 2004); Universal and national in philosophy: international scientific-practical conference of KRSU (27-28 of May 2004). Proceedings I under general editorship of I.I. Ivanova. Bishkek, 2004.

11. Kolosova O.Yu., Nesmeyanov E.E. Sociocultural transformations in the context of globalization processes // Fundamental research. 2015. No 2-14.

12. Kondrashov P.N. Lyubutin K.N. Globalization and the individual's development // Philosophy and Society. 2011. No 4 (64).

13. Kosolapov N.A. Freedom and lack of freedom in the global world order // International Processes. 2004. V. 2. No 6.

14. Kumskova N.V. Globalization and the polyvariance of socio-cultural models development // The Challenges of Modernity and Philosophy: The materials of "panel discussion" dedicated to UNESCO philosophy day. Kyrgyz-Russian Slavic University / Under the editorship of I.I. Ivanova. Bishkek, 2004. 
15. Lectorsky V.A. Globalization and cultural diversity // Lectures and reports of the RAS members in SBRHUTU (1993 - 2013): in 3 v. V. 3. SPb., 2013.

16. Marinov M.B. The life strategy of an individual in the individualized society: abstract of a thesis of Ph.D of philosophy: 09.00.11. Rostov-on-Don, 2008.

17. Maslov V.M. Freedom and virtual reality // Vestnik of the Chelyabinsk State University. 2008. No 10.

18. Mironov V.V. Modern transformations of culture // Lectures and reports of the RAS members in SBRHUTU (1993 - 2013): in 3 v. V. 1. SPb., 2013.

19. Mironov V.V. Dialogue of cultures and globalization threats // Lectures and reports of the RAS members in SBRHUTU (1993 - 2013): in 3 v. V. 3. SPb., 2013.

20. Rudenko A.M. About the need for a systematic approach to the formation of human security culture in modern Russia // The problem of human security in the modern world: a collection of materials on the results of the All-Russian Scientific and Practical Conference on April 11, 2017 / under the editorship of A.M. Rudenko [and others]. Novocherkassk, 2017.

21. Stepin V.S. Strategies for globalization and the cultures dialogue // Lectures and reports of the RAS members in SBRHUTU (1993 - 2013): in 3 v. V. 3. SPb., 2013.

22. Stepanova V.N. The family institution crisis as threat factor to the social security of modern Russian society // The problem of human security in the modern world: a collection of materials on the results of the All-Russian Scientific and Practical Conference of 11 April 2017 / under editorship of A.M. Rudenko [and others]. Novocherkassk, 2017.

February 12, 2018 